\title{
How libraries can survive in the new media ecosystem ${ }^{1}$
}

\author{
By Lee Rainie
}

\begin{abstract}
Resumen: Se comentan resultados de los estudios realizados sobre los cambios producidos en el ecosistema de la información y la comunicación en la era digital. Cómo se usan internet y la telefonía móvil para trabajar, jugar y para interactuar a través de las redes sociales. Este nuevo entorno ha cambiado la manera en que las bibliotecas y los bibliotecarios prestan servicio a sus usuarios. Se plantea la necesidad de que las bibliotecas se conviertan en "nodos" de las redes sociales de los ciudadanos.
\end{abstract}

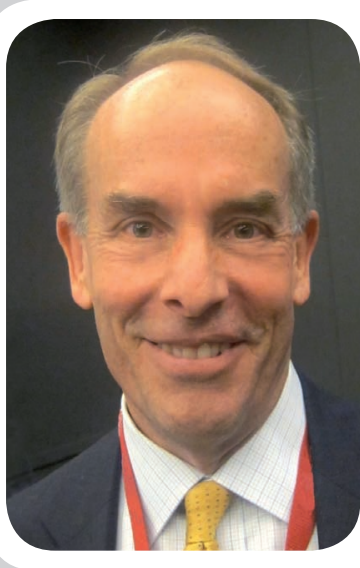
Lee Rainie is the director of the Pew Internet \& American
Life Project, a non-profit, non-partisan "fact tank" that stud-
ies the social impact of the internet. The Project has issued
more than 200 reports based on its surveys that examine
people's online activities and the internet's role in their lives.
Rainie is a co-author of Up for Grabs, Hopes and Fears,
and Ubiquity, Mobility, Security, a series of books about the
future of the internet published by Cambria Press and based
on Project surveys. He is also co-authoring a book for MIT
Press about the social impact of technology with sociolo-
gist Barry Wellman that will be published in late 2010 . The
working title is Networked: The New Social Network Oper-
ating System. Prior to launching the Pew Internet Project,
Lee was managing editor of U.S. News \& World Report. He
is a graduate of Harvard University and has a master's de-
gree in political science from Long Island University.

Palabras clave: Era digital, Internet, Sociedad de la información, Redes sociales, Networking, Bibliotecas.

\section{Title: How libraries can survive in the new media ecosystem}

Abstract: The results of studies on changes in the ecosystem of information and communication in the digital age are discussed., including how to use internet and mobile phones to work, play and interact through social networks. This new environment has changed the way libraries and librarians serve their users. The need for libraries to become "nodes" of the social networks of citizens is addressed.

Keywords: Digital age, Internet, Information society, Social networks, Networking, Libraries.

Rainie, Lee. "How libraries can survive in the new media ecosystem". El profesional de la información, 2010, mayojunio, v. 19, n. 3, pp. 308-314.

DOI: 10.3145/epi.2010.may.13

\section{Introduction}

PEW INTERNET is a unique kind of organization. We are funded by a major U. S. charity called the Pew Charitable Trusts to do original research about the social impact of the internet and, these days, mobile phones.

We research how people's use of technology affects their families, communities, health care, education, civic and political life, and work places. But we do this without promoting an agenda or advocating for particular policies, technologies, or companies.

We call ourselves a "fact tank" because our business is to generate information for people like you to assess and incorporate in your own work.

\section{An apology and a confession}

My apology is that I am very American. I was born and raised in New York, and I speak very fast. In the middle of my life, I moved to Washington, which is the center of American political culture, so I learned to speak like a lot of politicians.

My confession applies specifically to librarians. When I was applying for a grant in 1999 to the Pew Charitable Trusts, I wrote a section of the proposal about the types of people who would find our work important. I mentioned journalists, and policy makers, and scholars, and civic groups, but I did not use the words "library" or "librarian" in my proposal. I apologize to you for that!
I think I have made up for my sin since then because I learned very quickly that once we began to issue research reports, the greatest volume of comments came from librarians. I knew quickly that librarians would be primary consumers of our work, so in the grant applications that I made AFTER that first grant, I always was careful to say that librarians would be the NUMBER ONE group interested in our work.

I hope I have atoned for my original $\sin$ !

\section{Towards a new information ecosystem}

I know that librarians are interested in our work because their world is changing very dramatically. In the United States there was 
an important report written in 1996 by a major foundation/charity that spoke about the concerns librarians had about their future. The Benton Foundation is a friend of libraries, but its report was full of very troubling thoughts about the future of libraries.

The report contained quotations like this one from a library user, who was asked about the future of libraries in the digital age:

"If you plopped a library down,[...] 30 years from now [...] there would be cobwebs growing everywhere because people would look at it and wouldn't think of it as a legitimate institution because it would be so far behind [...]."

\section{“Libraries can be 'friends' in people's social networks"}

Yes, the world is changing very rapidly. One way I like to describe the difference is that the world has moved from an industrial era of media to a digital era of new media. In the industrial era, compared to now, information was relatively scarce, expensive, institutionally oriented and packaged for consumption. It took a lot of people and a lot of money to gather up information, make sense of it, and then sell the product to consumers. That's why we had big TV firms, newspaper conglomerates, publishers, movie studios, and record companies.

In the digital age, that world has been turned upside down. Information is abundant, cheap, personally oriented, and designed for participation. The biggest part of the change produced by the internet is that the creation and flow of information is now a two-way affair. Without great expenditures, individuals can be their own publishers, movie

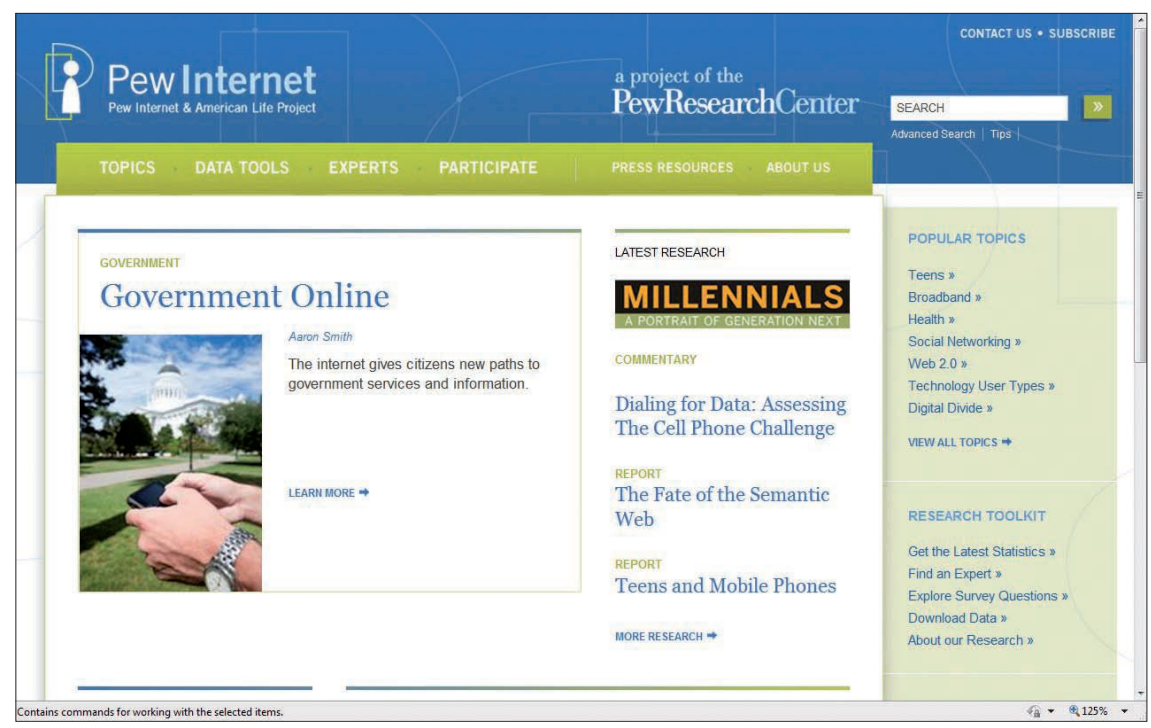

Pew-Internet

makers, and music creators in this world. Everyone can contribute to the media and information ecosystem.

\section{"Individuals can be their own publishers, movie makers, and music creators"}

The internet is the technology that intervened to turn the industrial media world into the digital media world. When my Pew Internet Project did its first research in March of 2000, we found that $46 \%$ of American adults (and $73 \%$ of teenagers) used the internet. Less than $5 \%$ of homes had broadband and the few that did were wealthy families who usually had their employers pay for this very expensive service.

Half the adults in the country had mobile phones.

No one connected to the internet wirelessly, except a very small handful of technology geeks.

And less than $10 \%$ of people used internet services in the "cloud." In other words, they had webmail accounts that stored their emails on someone else's servers, rather than on their own computers. Most information activities were built around personal computers. This was a world of slow, stationary connections tied to personal computers.

In just 10 years, that world has been dramatically changed. Our most recent data show that $75 \%$ of American adults use the internet -and $93 \%$ of teenagers do so. Some $62 \%$ now have high-speed, broadband connections at home. This is very important because people become very different internet users when they move from their slow, dial-up connections to always-on broadband connections. They use the internet more for all kinds of things. They report happier outcomes. And when they switch to broadband, the internet becomes a central information and communication utility in their lives.

Now, $80 \%$ of American adults have cell phones and $53 \%$ connect to the internet wirelessly, either through wireless cards in their laptops or through their smart phones or handheld devices. Again, this change to wireless connectivity has also had profound impacts on people's sense of when they can access the information they want and the people with whom they would like to share communication. 
A major part of that change has occurred because many Americans are storing their emails, their documents, their pictures, their videos, and their social networking communications "in the cloud." That is to say, they don't store as much of their material on their personal computers any more. They "leave it" in the cloud -someone else's servers- so that they can access it with whatever connected device or technology happens to be near them.

When it comes to using and creating media, it has become an anytime, anywhere world for most Americans.

\section{Media}

Another way to understand how profound this change is, would be to look at the change in the typical "media ecology" of a middle class home in the U.S. in just a generation. In the pre-internet era, this is the basic structure that existed: There were a few media products that were created. There were a couple of ways that those products got to the home. There were a few appliances on which they were displayed. And there were several ways that people stored media so that they could consume it again at a later date.

Now the home media ecosystem looks like this:

The number of information sources has exploded. The number of routes media and information use to get to the home has more than tripled. The number of devices that can display media has mushroomed. And the number of ways that we store media for future use has grown dramatically.

It literally will feel like we live in a data cloud when "things" are tied to the internet and information is coming, literally, from the environment of connected people and connected objects.
All this technology change is affecting basic social structures in a way that your great media research scholar Manuel Castells has described beautifully in his work on "networked society." The new digital ecosystem has changed social networks, the basic structure of our social interactions.

It has changed the composition of social networks. It has changed the way people use their social networks to navigate their lives. And it has increased the importance of social networks as people use them to make sense of the world.

And this new ecosystem changes the way organizations such as libraries can be parts of social networks. I believe that libraries have always been informal parts of people's social worlds as they help patrons solve problems and make decisions. This is even more clear now because libraries can be "nodes" or "friends" in networks thanks to the way libraries help people connect to important, useful information and, these days, help people learn how to become media makers themselves.

\section{"Networked individualism: people maneuver through looser networks to solve problems, make decisions and gain social support"}

\section{Behold networked individualism}

I am working on a book with a friend and colleague of Castells named Barry Wellman. He has been researching the change in social structures that was occurring before the internet came into being and has seen that these changes are now speeding up. Wellman's view is that social structures have moved from the tightly bound and close-knit groups of the family, the village, the farm, and the artisan's workplace, to a world where looser, networked social structures are common. We think this new world amounts to a new social operating system called Networked individualism, where people maneuver through looser networks to solve problems, make decisions and gain social support.

\section{Libraries in the networked individualism}

Now I would like to discuss the eight ways that the media ecosystem has changed, how that has affected the course of networked individualism, and how libraries can function in this new environment.

\section{Ecosystem 1}

The first big change is that the volume of information that is being generated has exploded. There are a variety of estimates about this. One major American firm has estimated that the amount of digital information would double in the five years between 2006 and 2011. Some scholars have calculated that the amount of information is growing $20 \%$ to $30 \%$ per year.

In human history, we have never seen this kind of growth in information. This is very disorienting to people as they try to keep up with all the media and information that is important to them.

\section{Ecosystem 2}

The second big change is that the variety of sources of information has grown and it is easier to find those sources with the powerful search engines that are available today.

At Pew Internet, one of the major things we measure is the generation of information by ordinary technology users. We believe that about two-thirds of adults and threequarters of teenagers have created content and shared it online. This 
amounts to a massive democratization of information sources and empowerment to technology users.

We measure this in several ways. The most important new development is the emergence of social networking sites such as Facebook, MySpace, Bebo, and Orkut.

\section{Social networking}

Some $57 \%$ of adults who are internet users and $73 \%$ of teenagers use these kinds of sites. They are sharing information about their lives, joining political causes, and passing along other media to each other through social networking sites.

There is a lot of concern about how much personal information people are willing to share on such sites and how their privacy might be compromised by people who can use this personal information to harm them. This, of course, adds to the stress that technology brings into users' lives.

\section{Picture sharing}

Another major way that people share material online is through photographs. Billions and billions of pictures are displayed on social network sites and photo-sharing sites. About half of online adults and more than two-thirds of teenagers have contributed photos online and our research shows they are considerably more social than other internet users. They are more engaged with others, know more about others, and are happy to let others get a peek into their lives as they post photo albums that detail events in their lives.

\section{Posting comments}

Another way that people contribute to online culture is to comment on others' material -on news sites, community sites, hobby sites, and political sites and many more. About a quarter of internet users have done this and contributed to the great, roiling conversation tak- ing place every minute in the online commons.

\section{Twitter}

The latest popular technology is Twitter -a micro-blogging system where people use 140 characters in a message answering the question "What are you doing?". About a fifth of internet users use status updating programs and give their "followers" little snapshots into their lives.

\section{Blogs}

Blogging was very exciting five or six years ago as many people took advantage of free tools to allow them to become publishers. About one in seven internet users currently have blogs and about half of internet users are regular readers of blogs.

\section{"Our attention is truncated or shortened, and we live in a state of 'continuous partial attention"'}

There are other content creation activities that we measure in the internet population: About $20 \%$ of people re-mix or "mash up" material they find online. They grab a photo or piece of writing or song and then change it -or "remix" itinto their own creation to share with others. About $15 \%$ of internet users have posted videos on web sites like YouTube or on their social networking pages. Another 15\% maintain their own personal websites.

So, the internet world is full of personal creations -and that is one of the big explanations for why there is so much more digital material in our lives. People are participating in making media, adding to their culture, telling their stories and building new kinds of communities with this material.

\section{Ecosystem 3}

The third change in the digital ecosystem is its impact on people's use of their time and attention. We see attention spans being changed in two ways. First, people's attention is truncated, or shortened. Technology users try to do many tasks at once -we call it multi-tasking and there is evidence that this hurts their ability to get things done.

I have a friend who has refined this idea smartly. Her name is Linda Stone and she argues that technology makes us all live our lives in a state of "continuous partial attention.” We keep all our gadgets ready to alert us whenever a new email, a new text message, a new phone call comes into our lives.

Linda worries that this adds stress to users' lives. They cannot afford to "leave the grid" because someone important like a work colleague or a family member might be trying to reach them.

At the same time, a second change in attention is happening. People can dive more deeply into the subjects that interest them. In our work at Pew Internet, we see that this happens many times when people are sick. They are very eager to do online searches for health information that will help them cope with their illness and even cure it.

Americans are debating how helpful it is that people can become "instant experts" on subjects that interest them. Some say we are in the Golden Age of "amateur experts" who are contributing to knowledge and working alongside experts with extensive training. Others like author Andrew Keen have written about how this is a problem because it allows people without expertise to act like publishers and create material that is biased or propaganda or hateful and might hurt people.

This is an important debate that librarians can influence. Many librarians in America are active in 
this debate and I suspect that is very much the case in other countries.

\section{Ecosystem 4}

The velocity of information has increased. Our work shows that is particularly true for the personal and particular information that matters to people. We all hear about big events pretty quickly. When a volcano erupts in Iceland and affects international plane travel or when European nations are debating how to bail out struggling economies, we all hear about that quickly.

\section{"We are in the Golden Age of amateur experts"}

The distinctive hallmark of this era is that fast information flows now affect the individual data streams we have all set up about the things that interest us. Some $84 \%$ of internet users in America belong to a group with an online presence and many have personal networks who also feed them information aroundthe-clock.

\section{Ecosystem 5}

The places or venues we have for encountering media and the availability of media has spread to every place and every time. People watch TV on their video iPods. They read newspapers on their laptops.

And the difference between the digital age and the industrial media age is that technology users now control the schedule of when they encounter and enjoy media. The media companies do not set the appointment time; users choose when they want media.

\section{Ecosystem 6}

The vibrance of virtual environments is becoming more compelling. The virtual world of data is being joined with the physical world in two special ways. The first is "augmented reality", where information is being layered over the environment.

There is an application for the iPhone (smart phone) that allows the user to point the phone at the nighttime sky, take a picture and the "app" will tell her what star constellation she sees. The phone has a chip that tells satellites where the user is standing, so the application "knows" where the user is oriented and can tell what star patterns are visible. That is augmented reality.

Another way that media environments have become vibrant is "mirror worlds" like Google Earth. These are compelling virtual representations of the real world. Before I travel, I use Google Earth to learn about my destination, the hotel, and people who have stayed there and told stories about meetings they attended.

In this new ecosystem, the real and the virtual are being blended.

\section{Ecosystem 7}

The seventh change is that the relevance of information that we seek is getting better as search engines improve, as members of our social networks feed us information, and as smart librarians create systems that make it easier for people to navigate to the material they want.

Nicholas Negroponte predicted in the early 1990s that people in the digital age would begin to customize and tailor information so that they would create the "Daily Me" with the material that mattered most to them. This is a reality now -about half of internet users have created something like a "Daily Me" data stream.

\section{"The media companies do not set the appointment time; users choose when they want media"}

\section{Ecosystem 8}

Finally, the eighth change is that people now "vote" and "ventilate" about the things they see online. They are participating in creating the digital ecosystem by ranking people, places, services, and news stories. About a third of American internet users are commenting about the things they see that matter to them and they are shaping the ecosystem with their "votes" and comments.

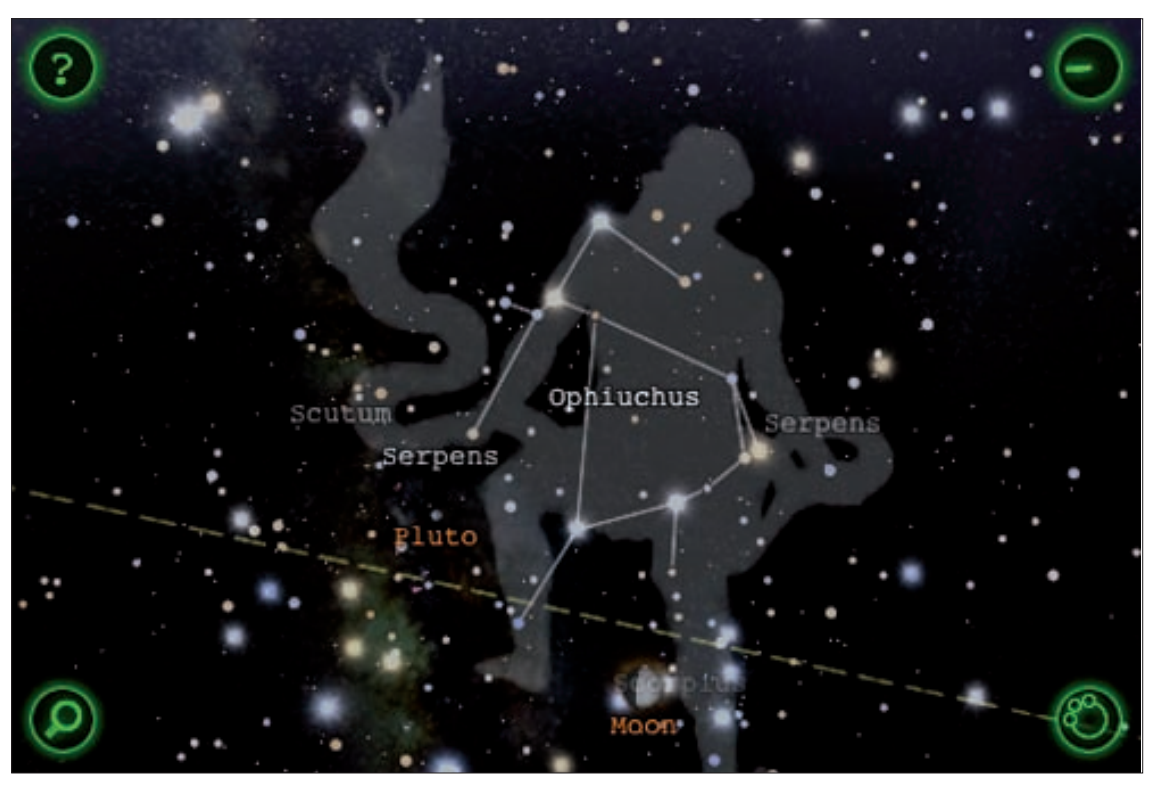

Ejemplo de realidad aumentada en un iPhone: enfocando el cielo se puede recibir el nombre de las constelaciones. Starmaps aloja 350.000 nombres de estrellas y 150 galaxias 


\section{What technology has done to social networks}

In this new ecosystem, networked individuals rely more and more on their social networks to help them get along in life. In a world where information is relentlessly swirling around them -more of it, from more sources, at higher speeds- social networks can be powerful sources of support and stability.

Technology has produced several important changes in the way social networks perform and the way librarians might be participants in them.

Technology has:

- made it possible for organizations like libraries to become "nodes" in people's networks that can help them solve problems and make decisions. When media making is a social activity, even organizations can have personalities and act in social ways;

- enabled the immediate, spontaneous creation of networks that can include libraries. When people are their own media creators and when they can reach out to many, many others online for help, then librarians can even better serve their mission to help others find what they need;

\section{"People have a strong sense that their social networks include 'consequential strangers' and 'audience members' who can help"}

- given people a sense that there are more "friends" in their networks, like librarians, who they can access when they have needs. People now have a strong sense that their social networks include "consequential strangers" and "audience members" who can help when they ask for guidance and assistance.

\section{Librarians can play a new rol in social networks}

This new ecosystem has changed the way that people encounter and use information, and that has changed the role that social networks play and changed the way influence works.

I see the flow of information and influence as a four-step process:

- How does material capture someone's attention?

- How do people acquire information once a subject has become interesting to them?

- How do people assess information that they gather?

- How do people act on that information once they need to make a decision or solve a problem?

I believe there are ways that librarians can act in each of those four stages as part of social networks to help their patrons.

\section{Attention}

How do you get the attention of your patrons?

- Use your traditional services (they still matter!). Many librarians worry that their services and skills might not be as acceptable in the new media ecology. What we hear from internet users is that those services and skills are even more valuable.

One new activity you can try with technology is to offer email and text alerts when new books arrive or when events are taking place. You can send messages updating patrons on your activities and you can provide feeds of information about the daily events at your organizations.

- Many librarians are trying to be available in "new" places -on social networking sites, on blogs, on Twitter, so that they can encounter patrons where they spend their time.

- And in this new ecosystem, some librarians find that the way to get attention from patrons is to send word to them through their social networks. In this world, friends are important as pathfinders to information.

\section{Acquire}

How can librarians help patrons acquire the information they are seeking?

- Librarians now think they help themselves by trying to serve patrons in many ways. They offer online services, e-books, technology training classes, video game parties, as well as the many traditional things they have done to attract patrons to their collections.

- They are also trying to find new ways to distribute their collections on new devices.

- One of the new "ethics" of information sharing is the "link." If they do not have the information themselves, librarians use links to point people to good material that is housed elsewhere.

- Finally, librarians watch blogs and social networking sites and Twitter for opportunity to have conversations about their work with people who are interested. These conversations build stronger relationships with patrons because librarians are "acting like friends."

\section{Assess}

How can librarians help patrons assess information? This is probably the most important part of serving in people's social networks. Librarians have always prided themselves on helping people find the best, most relevant information and that skill is even more important these days.

- The first part of the answer is for you to exploit your skills in 
knowing the highest quality material. This is your training and this is what patrons find most helpful about you.

- You do not have to know everything. It is good enough if you are able to find the best things and direct people to them. Your function as "aggregators" of collections and links is very important. Think of yourselves as "master teachers" -you don't know all the answers, but you know how to help people find the answers.

\section{Act}

How can you help your patrons act on the information they find? As I noted, the big change in the digital era is that people now have tools to become their own publishers and broadcasters. For many librarians, this means that they hope to be teachers of new digital literacies:

- how to use computers and the internet,

- how to be good search-engine users and think critically about the results they are given;
- how to create media in blogs, videos, pictures, or other creations;

- how to be safe and smart navigators in digital spaces;

- how to behave ethically in this new world where all kinds of social norms are being re-negotiated.

In addition, librarians are offering opportunities for citizens to act by giving feedback and building communities with new media.

\section{Why good social networks matter}

Being part of social networks should matter to librarians: They are the social groups people use to help them succeed in life. There is abundant social science research showing that those with big networks -of close friends and less-close acquaintances- and those with diverse networks are healthier, wealthier, happier, and they are more civically engaged, which means that effective networked individuals help create better communities.

\section{The importance of webs -not cobwebs, but social webs}

Remember the beginning of my talk when I described how Americans a few years ago were worried that libraries were dying institutions that might soon be filled up with cobwebs?

I hope my talk has helped you see that libraries are places of different kinds of webs. Not cobwebs.

Librarians can be essential friends to all their patrons in their social webs -their social networks. I believe librarians have a very bright future if they see this as their mission in the future. They are social "web" contributors -critical parts of social networks. And all of us who have ever had a librarian help us know exactly how important librarians can be -and where they can fit in our social networks.

\section{Note}

1. Speech by Lee Rainie to librarians in Barcelona, keynote to 12es Jornades catalanes de documentació (May 19, 2010); and Madrid, Sedic (May 21, 2010).

\section{Recibe el sumario de EPI por email}

Sé el primero en conocer el contenido de cada nuevo número de EPI. Mediante el servicio Alerting (servicio de alerta), cuando salga un nuevo número de EPI puedes recibir un email con el sumario.

\section{Para registrarte}

Entra en la web de EPI-MetaPress con tus claves de acceso:

http://elprofesionaldelainformacion.metapress.com/

Si no eres suscriptor también puedes registrarte, pues este servicio es gratuito.

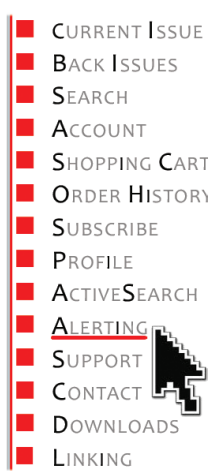

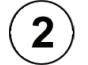

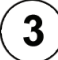

Alerting Publications

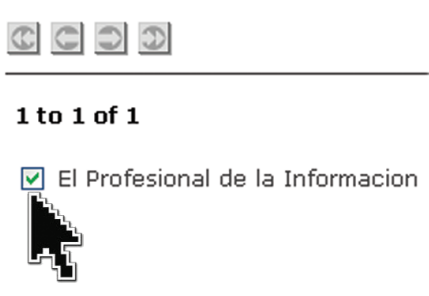

3

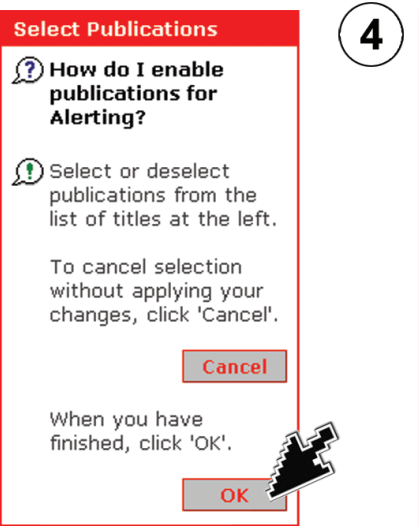

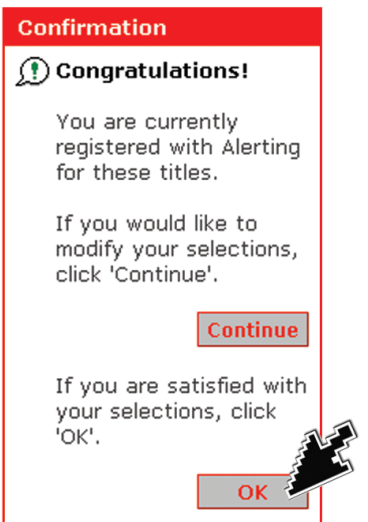

